\title{
Invited review: Udder health of dairy cows in automatic milking
}

\author{
M. Hovinen ${ }^{1}$ and S. Pyörälä \\ Department of Production Animal Medicine, Faculty of Veterinary Medicine, 00014 University of Helsinki, Finland
}

\begin{abstract}
Automatic milking (AM) is increasing in modern dairy farming, and over 8,000 farms worldwide currently use this technology. Automatic milking system is designed to replace conventional milking managed by a milker in a milking parlor or in tie stalls. Cows are generally milked more frequently in AM than in conventional milking, and milking is quarter-based instead of udder-based. Despite improvements in the milking process and often building of a new barn before the introduction of AM, udder health of the cows has not improved; on the contrary, problems may appear following conversion from conventional milking to AM. This review focuses on udder health of dairy cows in $\mathrm{AM}$, and we discuss several aspects of cow and milking management in AM associated with udder health. Finally, adequate management methods in AM are suggested. According to several studies comparing udder health between automatic and conventional milking or comparing udder health before and after the introduction of automatic milking in the same herds, udder health has deteriorated during the first year or more after the introduction of AM. Automatic detection of subclinical and clinical mastitis and cleaning the teats before milking are challenges of AM. Failures in mastitis detection and milking hygiene pose a risk for udder health. These risk factors can partly be controlled by management actions taken by the farmer, but AM also needs further technical development. To maintain good udder health in AM, it is imperative that the barn is properly designed to keep the cows clean and the cow traffic flowing. Milking frequency must be maintained for every cow according to its stage of lactation and milk production. Careful observation of the cows and knowledge of how to use all data gathered from the system are also important. "Automatic" does not mean that the role of a competent herdsman is in any way diminished.
\end{abstract}

Key words: udder health, automatic milking, mastitis detection, dairy cow

Received June 22, 2010.

Accepted October 26, 2010

${ }^{1}$ Corresponding author: mari.hovinen@helsinki.fi

\section{INTRODUCTION}

Automatic milking (AM) is one step in series of measures taken to automate dairy production. In many countries, the dairy industry is undergoing structural changes with farms growing larger. Because of high labor costs, automatic milking is becoming more common. Over 8,000 AM farms exist worldwide, $90 \%$ of which are in the northwestern Europe, including Scandinavia (de Koning, 2010).

Concern about cow udder health arises when housing or milking systems change, and particularly with an increasing herd size. Udder health may be affected by structural renovations in the barn, changes in management, and changes in cow-based factors. Along with the change from conventional milking $(\mathbf{C M})$ to $\mathrm{AM}$, cow cleanliness and cow movement, feeding systems, transmission routes of infections, and detection methods for diseases change. As dairy farms grow larger, staff time spent per cow decreases and the throughput of cows at milking increases. The milking process is different in AM and CM: milking frequency and intervals between milking, settings of the milking equipment, and procedures for teat dipping differ. Cleaning the teats before milking is done without the visual control of the milker, which increases the requirements for clean cows. Detection of mastitis is carried out automatically, without visual examination by the milker, who can notice at least clinical mastitis in CM. Furthermore, AM is quarter-based, which prevents the spread of IMI between teats of a cow and reduces overmilking. Possible spread of IMI between cows can no longer be prevented by milking order, but can be reduced by flushing or steaming of the liners between individual milkings.

Mastitis, an inflammation of the mammary gland that is almost always caused by bacterial infections (IDF, 1999), decreases milk quality and milk yield, causes economic losses and an increased workload for the farmer, and affects animal welfare. To maintain udder health of dairy cows, we need to understand the complex nature of the interaction between the cow, environment, management, and milking. In this context, $\mathrm{AM}$ is a rather new concept, and in this paper we review the present knowledge of the effect of AM on udder health. 
Table 1. Comparison of cow SCC in different published studies between farms with conventional milking (CM) or automatic milking (AM)

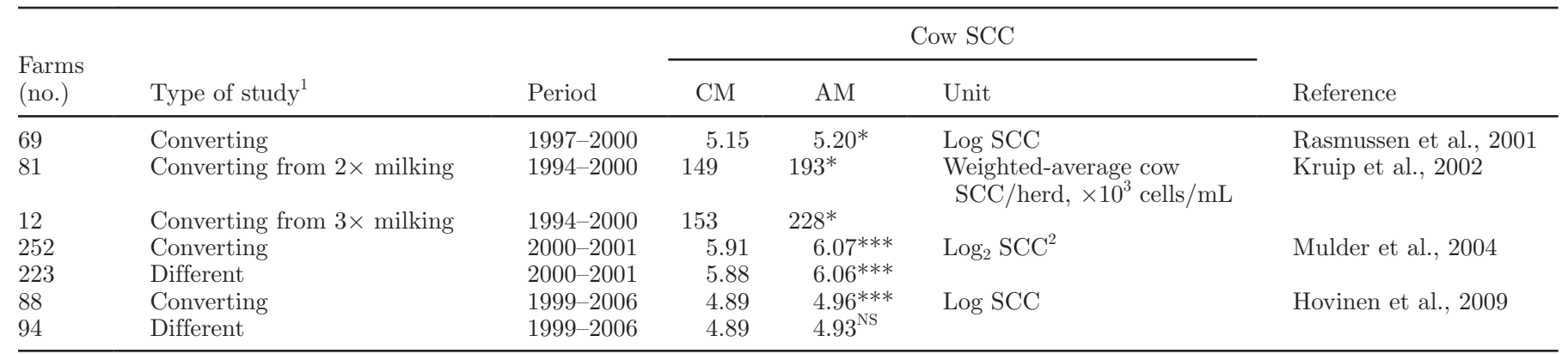

${ }^{1}$ Comparisons were made either on the same farms converting from CM to AM, or between different CM and AM farms according to test-day data.

${ }^{2}$ Binary logarithm, logarithm to the base 2, counted from SCS instead of SCC.

$* P<0.05 ; * * * P<0.001$.

\section{UDDER HEALTH IN AUTOMATIC MILKING- WHERE ARE WE NOW?}

Udder health of cows has been studied in epidemiological studies covering large numbers of dairy farms or at research farms having both AM and CM and evaluated using individual cow SCC in the milk, proportion of new high cow SCC, or number of mastitis treatments. Comparisons have been made between different $\mathrm{AM}$ and $\mathrm{CM}$ farms, and within farms before and after the introduction of AM.

Epidemiological studies have, in general, indicated deteriorating udder health among cows after the introduction of AM (Rasmussen et al., 2001; Kruip et al., 2002; Mulder et al., 2004; Poelarends et al., 2004; Pedersen and Bennedsgaard, 2006; Rasmussen, 2006b; Table 1). In a recent study conducted in 88 Finnish herds, the average cow SCC per herd and the proportion of new high-SCC cows was higher over the first year after the introduction of AM (Hovinen et al., 2009). Somatic cell count continued to be higher throughout the first year after the change. When these AM farms were compared with CM farms (nearly 200 farms in total) during the first year after the change in housing and milking systems, AM herds had more new high-SCC cows, and in mo 4, 10, and 12 after the change, a higher mean cow SCC than CM herds (Hovinen et al., 2009). Test-day SCC of first-parity cows from more than 250 Dutch farms increased after introduction of AM, and the increase lasted for $2 \mathrm{yr}$ after the introduction. When AM farms were compared with CM farms (more than 400 farms in total), a higher test-day SCC in first-parity cows was found in AM farms (Mulder et al., 2004). According to Danish data from 69 farms, SCC and the proportion of new high-SCC cows increased after introduction of AM (Rasmussen et al., 2001) but decreased after the adaptation period of a few months, although the proportion of new high-SCC cows among cows at risk was higher throughout the first year after the introduction. An adaptation period of a few months was also seen in Hovinen et al. (2009). In AM, milk SCC of the cows fluctuated more from low to high, indicating more new infections (Rasmussen et al., 2001). A more recent study of Rasmussen (2006b) on 478 AM farms supported earlier results, because the increase in the proportion of new high-SCC cows among cows at risk was still detectable after $4 \mathrm{yr}$ with AM. The increase did not depend on the year of the introduction or on the automatic milking system (AMS) brand.

The number of treatments of mastitis decreased after changing to AM in first-parity cows but increased in older cows (Hovinen et al., 2009). Changing to more intensive farming may leave less time to deal with individual cows and their treatments. Consequently, focus may be put on therapy at drying-off or premature drying-off of an individual quarter during lactation. The study of Pedersen and Bennedsgaard (2006) supports this, as they found that the proportion of cows with a blind quarter almost doubled during the first 6 mo after changing to AM. On the other hand, in support of our results in older cows, Bennedsgaard et al. (2004) reported an increase in antibiotic treatments for mastitis in 20 farms after the introduction of AM. Some of the farmers increased treatment frequency because they trusted the alerts from the automatic mastitis detection system, which may lead to an unnecessary increase in the use of antimicrobial drugs.

In contrast, studies comparing $\mathrm{AM}$ and $\mathrm{CM}$ in the same farm with similar environment and management indicated no differences in udder health of the cows measured as mastitis incidence (Wirtz et al., 2004) or cow SCC (Berglund et al., 2002; Abeni et al., 2008), although quarter SCC was lower in AM (Berglund et al., 2002). In that study, teats were cleaned both automatically and manually, which makes interpretation of 
the results difficult. Comparison of 2 farms operating on a pasture-based system revealed a higher incidence of clinical mastitis in $\mathrm{CM}$ than in $\mathrm{AM}$, but the herd size was twice as large and the proportion of heifers 4 times higher in the CM farms than in the AM farms and no statistical analysis was done (Lopez-Benavides et al., 2006).

Results from these studies show that udder health is negatively affected by a change from $\mathrm{CM}$ to $\mathrm{AM}$, and generally remains so in AM. Based on small-scale studies, however, good udder health can be achieved in AM, providing that proper management can be maintained. Increasing herd size and changes in the barn type may exacerbate problems in management brought about by the new type of milking. Increasing herd size has recently been associated with increased proportion of farms having a high incidence of clinical mastitis (Hill et al., 2009) and with an increased cow SCC in AM (Neijenhuis et al., 2010). In many farms changing to AM, a sudden need may arise for new cows to enable the farm to operate at full capacity. The purchased cows may not be of the best quality and can, for example, carry subclinical infections. Introduction of AM is often accompanied by other changes in the barn; for example, change from a tie-stall to a freestall system. In our recent study, a control group of 94 herds that changed from a tie-stall system to freestall barn was included to rule out the effect of the change in the barn type (Hovinen et al., 2009). Udder health deteriorated in the control herds as well but to a lesser extent than in the herds changing to AM, indicating that the effect on udder health depended more on the change in the milking system than on the change in the barn type. In some farms the AMS or a milking parlor may be installed in an old barn, which is not optimal and often results in problems in cow traffic, which in turn affects milking frequency in AM. Deterioration of udder health was noted already before the change of the milking system (Poelarends et al., 2004; Hovinen et al., 2009). The construction period causes extra stress for animals and people. Herds that had poor udder health before the introduction of AM were less likely to have good udder health after the change (Neijenhuis et al., 2010).

\section{FACTORS AFFECTING UDDER HEALTH IN AUTOMATIC MILKING}

\section{Number of Milkings and Length of Milking Intervals}

Milking frequency is increased in AM compared with CM, at least for most of the cows (Hogeveen et al., 2001). Increased milking frequency flushes bacteria from the udder more often, whereas long milking intervals (MI) provide bacteria with time to colonize the udder quar- ter following penetration of the teat canal after milking (Bramley et al., 1981). An increased milking frequency has generally been associated with less mastitis. Threetimes-a-day milking was shown to result in a decreased cow SCC (Klei et al., 1997) compared with twice-a-day milking. Köhn et al. (2007) reported a slightly negative correlation between cow SCC and milking frequency in 10 farms with AM and free cow traffic. In a study including more than 900 cases of clinical mastitis in AM herds (Rasmussen et al., 2007), MI increased by approximately $2 \mathrm{~h} / \mathrm{d} 1 \mathrm{mo}$ before treatment of mastitis. It was suggested that this indicated that cows' daily rhythms were affected by the disease and that the increased MI may have enhanced development of clinical mastitis in quarters with subclinical mastitis. On the other hand, frequent milking provides greater opportunities for bacterial invasion during milking, and teat canals remain open after every milking, exposing quarters to environmental bacteria (Hillerton, 1991). Short MI also leave less time for the teats to recover from milking, which could have an adverse effect on teat condition (Ipema and Benders, 1992).

Increased cow SCC in AM was assumed to be mainly caused by the irregularity of milking (Kruip et al. 2002), but little data are available to support this assumption. On the one hand, long milking intervals (once-a-day milking) impair tight junctions, causing an influx of somatic cells into milk, and this influx of neutrophils into milk seems to continue even after twice-a-day milking has resumed (Stelwagen and Lacy-Hulbert, 1996). The explanation for this is likely the increased pressure of the milk in the mammary gland. On the other hand, if the time since the last milking is less than $3 \mathrm{~h}$, even healthy quarters can have an SCC close to 200,000 cells/mL (Olde Riekerink et al., 2007); the latter study found that the geometric mean SCC was increased until $7 \mathrm{~h}$ after milking. The explanation for this relied on a hypothesized high influx of cells shortly after milking, followed by a slow dilution with the increasing milk volume for hours. Irregular milking frequency (a weekly coefficient of variation of $\mathrm{MI}>23 \%$ ) decreased the rate of milk synthesis (Bach and Busto, 2005). In contrast, Weiss et al. (2002) found no differences in quarter SCC relative to udder filling when cows were milked at irregular intervals by AMS. The question of whether the irregularity affects the dynamics of somatic cell recruitment into milk only or also milk synthesis remains open. However, it is likely that too short or too long MI at regular intervals would be even more detrimental for the udder.

In AM, milking permission is given, for example, on the grounds of the expected milk yield or the time since last milking, or it may be counted based on DIM and milk yield. However, the intended milking frequency 
may differ from that really taking place. On an experimental farm with AM, the average MI was $9.2 \mathrm{~h}$, but $27 \%$ of the MI were $<6 \mathrm{~h}$ or $>12 \mathrm{~h}$ (Hogeveen et al., 2001). In a study on 8 commercial herds, approximately one-third of the MI were $<6 \mathrm{~h}$ or $>12 \mathrm{~h}$ (Gygax et al., 2007 ). Use of a waiting area was associated with better udder health in a study by Neijenhuis et al. (2010). Reasons were not clear but this might have been related to an increased milking frequency or more even MIs.

\section{Fluency of the Milking Process}

Kaihilahti et al. (2007) investigated 300 milking and cleaning processes on an AM farm and found that $5 \%$ of the milkings failed due to machine problems and $3 \%$ due to the cow. Only one-third of all deviations were successfully compensated for by the robot. Other studies have shown consistent results with $8 \%$ or from 4 to $5 \%$ of the milkings failing (Bach and Busto, 2005; Jago et al., 2006). Gygax et al. (2007) showed that attachment of the teat cup was successful in 94 to $98 \%$ of the milkings, depending on the AMS used. An increased distance between the fore teats, especially in old cows, and a decreased distance between the hind teats in first-parity cows, created most of the problems in the attachment of the milking cups (Miller et al., 1995). Incomplete emptying of the udder may lead to milk leakage (Stefanowska et al., 2000; Persson-Waller et al., 2003), discomfort of the cows (Stefanowska et al., 2000), impaired milk ejection in the affected and unaffected quarters (Bach and Busto, 2005), and a disturbed milking routine. Up to 9 milkings per day were recorded for cows with failed milkings (Klaas et al., 2008). Frequency of unsuccessful milkings increased from 5 to $30 \%$ during $1 \mathrm{wk}$ before clinical mastitis (Rasmussen et al., 2007), which could mean that mastitis disturbed the milking routine.

For milk ejection reflex to occur in time in AM, teat preparation is necessary if milking starts immediately after attachment of the first teat cup (Dzidic et al., 2004a). Without teat brushing, the dead milking time (time without detectable milk flow) for the first 3 attached quarters increased in AM (Jago et al., 2006). Teat preparation of AMS has been shown to be sufficient for milk ejection (Bruckmaier et al., 2001; Hopster et al., 2002; Mačuhová et al., 2003; Dzidic et al., 2004a), independent of the teat preparation method; that is, brushing or cleaning with a cup of warm or cold water (Dzidic et al., 2004a,b). With a low degree of udder filling after a short MI or a low milk yield in cows in late lactation, enough time for the teat preparation should be made possible by specific adjustments (e.g., requesting more than one brushing sequence; Bruckmaier and Hilger, 2001; Dzidic et al., 2004a). Time from the first touch of the udder to the attachment of the last milking cup was considerably (3 to 4 times) longer for AM than for CM in an auto-tandem parlour (Gygax et al., 2007). On the other hand, prolonged attachment in AM had no adverse effects on oxytocin release (Mačuhová et al., 2004). Dzidic et al. (2004a) suggested that permission for milking could be based on the actual degree of udder filling (a proportion of milk yield compared with the maximum storage capacity of the cow in mo 2 of the respective lactation).

\section{Teat Condition}

Quarter-based milking in AM reduces overmilking compared with whole udder milking (Hogeveen et al., 2001), especially in the fore teats. Overmilking results in deteriorated teat condition (Hillerton et al., 2002). Some systems also provide a possibility for quarter pulsation, which might represent an opportunity to determine suitable settings for individual quarters, but to date no studies have assessed the effects of quarter pulsation on teat condition in AM. This option in AM could reduce machine on-time for a quarter. Reduced machine on-time, especially at the end of milking when milk yield in the quarter is decreasing, enhances maintenance of good condition of the teats (Rasmussen, 1993; Neijenhuis et al., 2000). This in turn could decrease the incidence of clinical mastitis (Neijenhuis et al., 2001b; Breen et al., 2009), because teat-end callosity inhibits teat closure after milking, and a rough callosity ring may harbor mastitis-causing bacteria (Neijenhuis et al., 2001b). On the other hand, with short MI, milk flow rate decreases and daily machine on-time becomes longer (Hogeveen et al., 2001). Milking 4 times a day negatively affected teat condition, because of the short time left for teats to recover from the previous milking (Ipema and Benders, 1992). As Neijenhuis et al. (2001a) showed, milking can affect teats for much longer than is usually believed; teat canal width was increased for up to $8 \mathrm{~h}$ after milking, and therefore MI should not be too short.

On 15 farms that changed from CM to AM, vascular disturbances of the teats due to milking, teat skin condition score, and teat-end callosity decreased after the introduction of AM (Neijenhuis et al., 2004). The proportion of blue teats after milking increased, however, but the reasons for this were not discussed. The condition of the teat skin was worse in AM, but more vascular disturbances and teat-end callosity were seen in CM (Berglund et al., 2002). Only a few cows with a high degree of teat-end callosity were recorded on $8 \mathrm{AM}$ farms (Klaas et al., 2008). Parity, season, variation in milk flow, failed milkings, and milking frequency were associated with the condition of the teats. Contradic- 
tory results were reported in Finland, where teat-end callosity increased and teat skin condition deteriorated on 3 farms after the introduction of AM (Hovinen and Pyörälä, 2002). The negative effects decreased by increasing the switch-level of the AMS and changing the teat spray to promote a greater moisturizing effect. A study comparing 20 cows that changed from CM to AM revealed no adverse effects for teat skin condition, but teat end condition deteriorated in heifers but improved in older cows (de Vliegher et al., 2003). Teat end and teat skin condition was worse when cows were milked more frequently, but this was not suggested as the cause for the differences between age groups of the cows.

\section{Bacterial Ecology}

Barn environment affecting the bacterial ecology is, in principle, the same in freestalls with $\mathrm{AM}$ and CM, but milking-related factors such as the transmission routes of bacteria differ. Quarter-based milking in AM inhibits cross contamination of the teats with udder pathogens within a cow. However, transfer of bacteria between cows can occur through the automatic milking unit (AMU). Segregating cows with udder health problems is possible but requires special arrangements with several barn compartments. Traditional milking order, in which infected cows are milked last, has been substituted in AM with rinsing or steaming milking liners between cows. In CM, back flushing of the liners was demonstrated to cut the number of staphylococci by $99 \%$, but it did not affect the incidence of clinical mastitis (Smith et al., 1985). In AM, back flushing removed $98 \%$ of Streptococcus agalactiae from artificially contaminated liners, and none of the quarters of 46 cows milked with or without cluster flushing became infected (Schuiling and Neijenhuis, 2004). In contrast, after milking of cows infected by Staphylococcus aureus, bacteria were detected in the liners of AMS after liner flush as often as in CM without liner flushing (Hovinen et al., 2010). Steaming the liners after milking was not associated with udder health in an epidemiological study on 144 farms reported by Dohmen et al. (2010), but in that study steaming was used in only $16 \%$ of the milkings, which might explain the missing association. Regular changing of liners is important.

Milk from infected quarters is a major source of new infections for other cows. Open teat canals expose the quarters to bacteria originating from the environment or from other cows (Bramley et al., 1981; Hillerton, 1991). Cows leaking milk are more susceptible for IMI but can also spread infections. Proportion of studied cow-days and individual cows leaking milk were higher in AM than in CM (Persson Waller et al., 2003). Milk leakage was recorded more frequently in primiparous cows, hind quarters, quarters with a high milk flow, and cows lying down. Unsuccessful milking could also have resulted in some leaking of milk. Teat dipping after milking when the teat canals are open protects the quarters from infections (Pankey et al., 1984). All AMS include an opportunity for postmilking teat disinfection, but its reliability in covering the teats properly is debatable. In a Danish study only half of the 42 cows studied had all their teat ends covered with teat spray from an AMU (Rasmussen and Hemling, 2002). Proportion of teats not covered with teat spray was associated with the proportion of new high-SCC cows; in $18 \%$ of the milkings on $144 \mathrm{AM}$ farms, teats were not covered with spray at all (Dohmen et al., 2010).

Distribution of mastitis-causing bacteria isolated in IMI in AM herds has not been exhaustively studied, and it is not known if it differs from that in CM herds. In 18 Danish farms the prevalence of CNS increased from $14 \%$ in CM to $23 \%$ in AM in the older cows after the introduction of AM. In particular, the incidence of subclinical mastitis caused by CNS was significantly higher during early and late lactation (Pedersen and Bennedsgaard, 2006). Transfer of bacteria by the AMS teat-cleaning device was suspected to be one cause for the increased infections. In 3 German AM farms, environmental streptococci and CNS were the main causes of subclinical mastitis (Petermann et al., 2002). In Sweden, comparison of cows on 1 farm with both milking systems revealed that CNS was most prevalent both in AM and CM (88 and $74 \%$ of the bacteria found, respectively; Berglund et al., 2002). In a pasture-based system in New Zealand, prevalence of IMI seemed to be caused more often by contagious bacteria (Staph. aureus and Corynebacterium bovis) in AM and mainly by environmental bacteria (Streptococcus uberis) in CM, although CNS were most commonly isolated in both AM and CM (Lopez-Benavides et al., 2006).

In an AM herd where the prevalence of Staph. aureus IMI at calving was $3 \%$ of the cows, infection spread to $67 \%$ of the cows during the 1-yr study period (Zecconi et al., 2004). In an AM herd of about 100 cows, 15 developed coliform mastitis, most of which were caused by Klebsiella spp. (Tuiskunen et al., 2006). Bacteria were isolated in several sites of the AMU and in stalls where an infected cow had been lying. A similar case was reported in Sweden, where Klebsiella bacteria were possibly transferred to the cows by contaminated teat cleaning brushes of the AMU (Persson Waller and Unnerstad, 2004). Wendt and Pallas (2004) studied 2 AMS herds and suggested that suboptimal cleaning and disinfection of the AMU (brushes, liners, and the multipurpose arm), as well as insufficient postmilking disinfection of the teats, resulted in high mastitis prevalence in the herds. These findings highlight the 
importance of proper AMU management, because the AMU can be responsible for the transmission of infections between cows.

\section{Teat Cleaning in Automatic Milking}

Milking hygiene has an effect on the udder health of cows, because pathogens can enter the teat canal during milking, especially during overmilking (Thiel et al., 1969). Poor udder and teat hygiene has been associated with a high incidence of clinical mastitis (Breen et al., 2009), a high cow SCC (Schreiner and Ruegg, 2003; Dohmen et al., 2010), and a high incidence of IMI (e.g., Schreiner and Ruegg, 2003). In AM, dirty teats before milking were a risk factor for having an increased proportion of new high-SCC cows and high SCC in the herd (Dohmen et al., 2010). According to European Union legislation, milking must be carried out hygienically and teats, udders and the adjacent areas must be clean before milking [Regulation (EC) No 853/2004]. An AMU cleans the teats with automatic devices, without the visual control of the milker as in CM. No method is available to distinguish between dirty and clean teats before cleaning or for monitoring the effectiveness of the cleaning (Mottram, 1997). However, such technologies have been investigated (e.g., Bull et al., 1995). Current AMS do not have sensors to detect whether a teat is in the cleaning device during cleaning or if the teat is actually cleaned.

Technical Success of Teat Cleaning. Limited research on the effectiveness of teat cleaning (ETC) and the technical success of teat cleaning (TSTC) in AM is available. Eight percent of teat cleanings per cow failed due to machine problems and $4 \%$ because of cow-related problems, including kick-offs (Kaihilahti et al., 2007). Jago et al. (2006) found only $67 \%$ of the cleanings to be technically successful; that is, all 4 teats were brushed. In a field study on 9 farms, TSTC was unsatisfactory for more than one-third of the cows tested (Hovinen et al., 2005). In the best performing farm, over $95 \%$ of the teat cleanings were technically successful. Reasons for most of the failed teat cleanings were undetermined (Hovinen et al., 2005). Causes of the unexplained, unsuccessful cleanings are probably technical, as reported by Kaihilahti et al. (2007). Of the known causes, an undefined device failure in one herd and restless behavior of the cows in several herds were associated with most of the totally unsuccessful teat cleanings, whereas abnormal udder and teat structure was associated with most of the partly unsuccessful teat cleanings (Hovinen et al., 2005). Most of the unsuccessful brushings were unsuccessful during both rounds of cleaning.
Different problems in TSTC may be expected in teat cleaning done using a cup or brushes. In cup cleaning, where $10 \%$ of the unsuccessful teat cleanings failed because of cow restlessness, cows can move after localization of the teat, teats can slip away from the cup, or the cow can kick the cleaning cup off the teat (Hovinen et al., 2005). Jago et al. (2006) reported 0.1 kicks/brushing. Black teat pigmentation and long udder hair were associated with unsuccessful teat cleanings during cup cleaning of the teats (Hovinen et al., 2005). For teat brushing, where the teat is not localized before cleaning, 20 to $50 \%$ of the unsuccessful teat cleanings were linked to restless cows or cows standing so that the system could not function properly (Hovinen et al., 2005). Abnormal udder and teat structure was significantly associated with TSTC only in teat brushing (Hovinen et al., 2005).

Effectiveness of Teat Cleaning. After proper manual teat cleaning in CM, no visible dirt should remain on any part of the teat. In that respect, teat cleaning in AM is inferior to well-conducted manual teat preparation (Hovinen et al., 2005). In other field studies with bacteriological and visual evaluation of cleanliness of the teats, teat cleaning in AM has been shown to be less effective than manual cleaning (Knappstein et al., 2004; Bade et al., 2008). Teat orifice is less effectively cleaned than teat barrel or apex, and teat condition affects ETC (Hovinen et al., 2005). Bacteria and sediment on the teat orifice have direct access to the teat canal and they also end up in the raw milk. Also, in experimental AM studies where the initial contamination of the teats was standardized, teat cleaning has been less effective than manual cleaning (Schuiling, 1992; Knappstein et al., 2004). One experiment measuring spore content of the milk after artificial contamination of the teats furnished contradictory findings: a cleaning cup was more efficient than manual cleaning with fresh moist tissue paper (Melin et al., 2002). However, artificial contamination of the teats may not be equated with natural dirtiness of the teats.

Using visual evaluation of the cleanliness of the teats, $69 \%$ (Knappstein et al., 2004) and 35\% (Hovinen et al., 2005) of them were considered totally clean after teat cleaning. In Dohmen et al. (2010), $8 \%$ of the cows still had dirty or very dirty teats after cleaning in AM. Teat cleanliness before cleaning has a major influence on ETC, and large differences in teat cleanliness before cleaning have been found in published studies (Knappstein et al., 2004; Hovinen et al., 2005). In one study, about $45 \%$ of dirty and extremely dirty teats remained dirty (Hovinen et al., 2005) and requirements of the ISO standard ISO/DIS 20966 (ISO, 2007) for automatic milking installations were not met. In the 
study of Knappstein et al. (2004), bacterial counts on the teats even increased in some herds during cleaning. Differences between the herds were greater than differences between the teat-cleaning methods for ETC (Knappstein et al., 2004; Hovinen et al., 2005). Teat cleaning was more effective with a cleaning cup than with brushes, especially for extremely dirty teats (Hovinen et al., 2005). In contrast, the study of Knappstein et al. (2004) indicated that extremely dirty teats were cleaned more effectively with brushes, and vice versa in slightly soiled teats.

Based on these studies, cleanliness of the teats before cleaning contributes most to the outcome of the teat cleaning. Consequently, cow cleanliness is even more important in AM than in CM. Barn design and cow comfort have a great effect on cow and udder cleanliness (Cook, 2004), and AM barns should be designed with the help of experts on animal health and welfare.

\section{Mastitis Detection in Automatic Milking-What Should Be Detected and When?}

Subclinical Mastitis. By definition, subclinical mastitis is not visible and requires a diagnostic test for detection (IDF, 1999); cow milk SCC of $>200,000$ cells / $\mathrm{mL}$ indicates mastitis (Schukken et al., 2003). Mastitis should be detected in a reliable and timely fashion (Pyörälä, 2003) or subclinical mastitis can develop into clinical disease. Cows with undetected mastitis also represent an infection risk for other cows. Cow SCC of $>200,000$ to 300,000 cells/mL should be detected to initiate preventive or therapeutic measures (e.g., frequent milking, treatment with antibiotics, preventing transmission of the infection to other cows; Hamann and Zecconi, 1998). We believe that most farmers would like to identify the quarters for economic (Halasa et al., 2009) as well as for herd health purposes.

Clinical Mastitis and Automatic Separation of Milk. Clinical mastitis is characterized by visible abnormalities in the milk, in the udder, or in both (IDF, 1999). Milk from cows with clinical mastitis can contain high numbers of bacteria, and may transmit the infection to other cows. The cow should be treated as soon as possible to support the elimination of bacteria from the udder quarter and to control pain and inflammation. Mein and Rasmussen (2008) claimed that most farmers would like their AMS to detect and separate abnormal milk, to alert the owner of those cows that should be treated for clinical mastitis or culled, and to identify the correct time point for delivery of the milk after treatment. They also agreed with Kamphuis et al. (2008b) in that abnormal milk and milk from a quarter with clinical mastitis should be subject to different classification models so that abnormal milk would be detected with a high sensitivity, and only a few false positive alerts indicating clinical mastitis would occur. Milk with a yellow color is not always an indication of mastitis, and ideally the system should not be oversensitive to these cases (Hovinen et al., 2006). Automatic milking systems have been given credit for providing early alerts for mastitis detection. Alerts are given if the composition of the milk changes; that is, an "early alert" takes place at the stage of subclinical mastitis. If the farmer does not pay attention to subclinical mastitis, early alerts will only lead to frustration. Kamphuis et al. (2010a) concluded that to be useful, an alert should be given at the first milking when clinical mastitis is present or during a very short time before.

European Union legislation [Regulation (EC) No 853/2004] states that milk has to come from animals without signs of clinical mastitis. Consequently, AMS should be able to separate abnormal milk automatically. To avoid separating normal milk, the evaluation method should be highly specific for healthy quarters. In the ISO standard for automatic milking installations (ISO/DIS 20966; ISO, 2007), methods for automatic detection of abnormal milk should have sensitivity (Se) $>70 \%$ and specificity $(\mathbf{S p})$ of $>99 \%$. In the tests performed according to the guidelines of the ISO standard, Se for automatic separation of milk has ranged from 28 to $45 \%$ for abnormal milk [>2 mm visible clots in milk with Californian Mastitis Test (CMT) score >3] depending on the AMS model and was $100 \%$ for milk with blood ( $>2 \%$ of blood in milk; Rasmussen, 2006a). In AM, milk from one quarter with a high SCC is not separated as in CM, but if technically possible, separating milk from individual quarters could be preferable for economic reasons (Forsbäck et al., 2009).

Interpreting the Results of Mastitis Detection to the Farmer. An alert is a farmer-friendly way of interpreting the results of a sometimes complex set of udder health indicators of the AMS, using milk quality data and other cow-specific data. In current AMS different ways of expressing an alert (verbal, symbols, counters, color coding, or phone messages) exist based on calculating absolute or index values, classes, or inter-quarter relations between the quarters. Absolute values are easiest to adjust. The algorithms behind the index values are usually proprietary knowledge of the AMS manufacturer and are not open for discussion or adjustments, which makes their usefulness debatable. Farmers should be made aware of the theory, basis, and thresholds of the detection system. Thresholds for alerts should be flexible between farms (Kamphuis et al., 2008b). Consequently, the farmer could choose between having more alerts with greater precision and more false positives (FP) versus fewer alerts with lower Se, depending on the udder health status of the herd 
Table 2. Performance of electrical conductivity and milk color measurement for detecting subclinical mastitis according to different studies

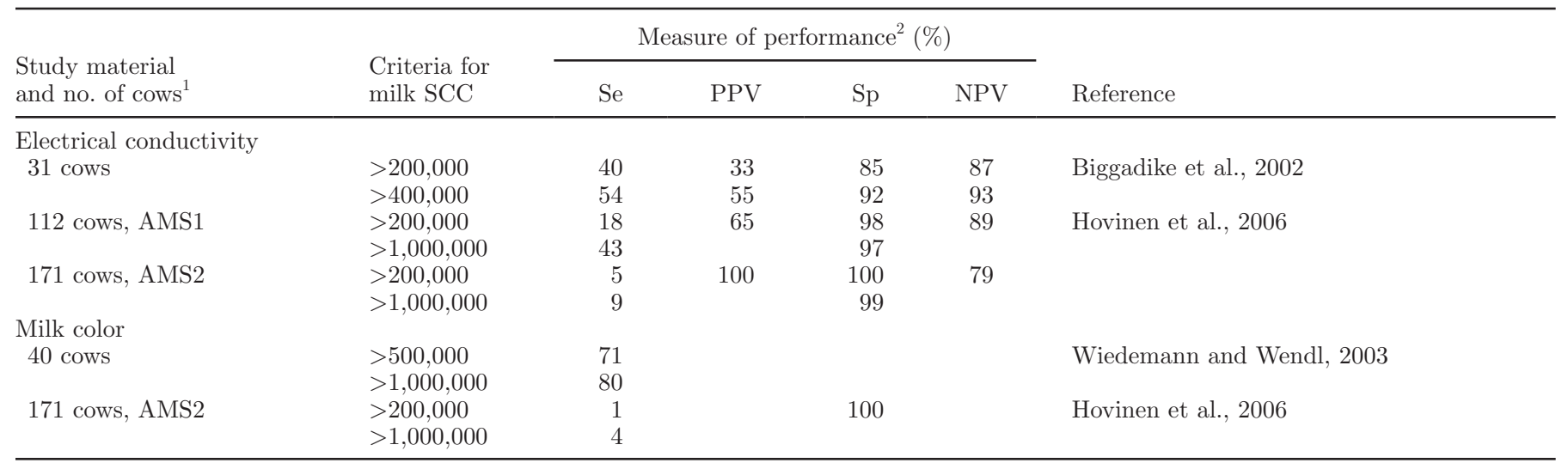

${ }^{1} \mathrm{AMS} 1$ and AMS2 are different brands of automatic milking systems.

${ }^{2}$ Sensitivity (Se), specificity (Sp), positive predictive value (PPV), and negative predictive value (NPV) were used as a measures of performance. The thresholds and mathematical models for alerts and time windows for creating and classifying alerts varied.

and methods used to monitor udder health. Furthermore, farmers should be able to design their own alert list, using parameters they prefer, and a coding system for the alerts they find easiest to understand.

\section{Methods for Mastitis Detection in Automatic Milking}

In AM different types of on-line devices have been installed for detection of mastitis. Most of them are based on measuring characteristics of milk continuously from the milk line. This enables the use of different mathematical methods to process the data: inter-quarter comparison of the values, calculating running averages of the parameters (Maatje et al., 1992), analyzing patterns of milk variables during milking, or picking up maximum and minimum values during milking (Norberg et al., 2004). On the other hand, some characteristics of AMS may complicate the use of the data: measurement errors or missing data, unequal numbers of observations within milking between the cows, and dependency on subsequent measurements within and between milkings (Nielen et al., 1995). In addition, using multivariate methods with external information about the cow combined as intelligent knowledge-based methods and decision-making systems have been suggested (Hogeveen et al., 1991; de Mol et al., 2001; Steeneveld et al., 2008). Performance of these different methods in AM for mastitis detection is presented in Tables 2 and 3.

Electrical Conductivity. Electrical conductivity (EC) is the most common and widely studied indicator used to detect subclinical and clinical mastitis in the current models of AMS. An on-line method for measuring EC was developed because of its technical simplicity and low cost. The measurement is based on the increase in $\mathrm{Na}^{+}$and $\mathrm{Cl}^{-}$in the mastitic milk due to inflammation of the mammary gland, which increases the permeability between milk and blood compartments (Hamann and Zecconi, 1998). According to an abundance of studies, measuring milk EC is an inadequate method to detect subclinical mastitis (Nielen et al., 1992; Hamann and Zecconi, 1998; Biggadike et al., 2002; Bruckmaier et al., 2004; Norberg et al., 2004; Hovinen et al., 2006; Table 2) or clinical mastitis (Hamann and Zecconi, 1998; Table 3), and abnormal milk in general (Rasmussen, 2004). In a field study (Hovinen et al., 2006), Se of EC for detecting mastitic quarters (single sample, SCC >200,000 cells $/ \mathrm{mL}$ ) ranged from 5 to $18 \%$, depending on the AMS. When mastitis was defined as SCC $>1,000,000$ cells $/ \mathrm{mL}$, Se ranged from 9 to $43 \%$. Detection of quarters with a confirmed IMI generally failed. In a small number of clinical cases of mastitis, Se of EC was comparable to the average Se of milkers (70 to $80 \%$ ) to detect abnormal milk by visual observation (Rasmussen, 2005). In AM, 12 out of 29 cases $(41 \%)$ of clinical mastitis were detected with EC from $1 \mathrm{~d}$ to 1 milking before the visual observation (Knappstein and Reichmuth, 2000).

On the basis of results from studies using experimental mastitis models, milk EC starts to increase after SCC (Bruckmaier et al., 2004) but before clinical signs appear (Maatje et al., 1992; Milner et al., 1997). It has been proposed that antibiotic treatment of mastitis could be started based on the so-called early warning system of EC (Maatje et al., 1992; Milner et al., 1997). This suggestion was, however, based on an experimental mastitis model in which the quarter was treated with antibiotics immediately after the increase of EC, and subsequently a favorable response could be expected. Results from field studies suggest that this practice is 
Table 3. Performance of electrical conductivity, milk color, and milk SCC measurement for detecting clinical mastitis in automatic milking, according to different studies

\begin{tabular}{|c|c|c|c|c|c|c|}
\hline \multirow[b]{2}{*}{ Study material ${ }^{1}$} & \multirow{2}{*}{$\begin{array}{l}\text { Criteria and alert period } \\
\text { for clinical mastitis }\end{array}$} & \multicolumn{4}{|c|}{ Measure of performance ${ }^{2}(\%)$} & \multirow[b]{2}{*}{ Reference } \\
\hline & & Se & PPV & Sp & FAR or FP & \\
\hline \multicolumn{7}{|l|}{ Electrical conductivity } \\
\hline \multirow[t]{2}{*}{29 cases } & $1 \mathrm{~d}$ to 1 milking before clinical mastitis & 41 & & & & \multirow[t]{2}{*}{ Knappstein and Reichmuth, 2000} \\
\hline & Actual milking or after clinical mastitis & 21 & & & & \\
\hline \multirow[t]{2}{*}{6 farms, different AMS } & $\begin{array}{l}\text { California Mastitis Test (CMT) } \geq 3 \text { and } \\
\text { clots in milk, actual milking }\end{array}$ & $0-71$ & & $96-100$ & & \multirow[t]{2}{*}{ Rasmussen, 2004} \\
\hline & CMT $\geq 3$ and clots in milk, same day & $17-100$ & & $92-100$ & & \\
\hline \multirow{2}{*}{$\begin{array}{l}4 \text { farms, AMS1, } 7 \text { cases } \\
4 \text { farms, AMS2, } 17 \text { cases }\end{array}$} & Visually abnormal milk and $\mathrm{CMT} \geq 3$, same day & & & & & \multirow[t]{2}{*}{ Hovinen et al., 2006} \\
\hline & & 59 & & & & \\
\hline 1 farm, 20 cases & Visually abnormal milk or local signs of the udder ${ }^{3}$ & 80 & $7-11$ & & FAR 5-8 & Kamphuis et al., 2008b \\
\hline 3 farms, 22 cases & Visually abnormal milk & 32 & 14 & & FAR 49 & Mollenhorst et al., 2009 \\
\hline 3 farms, 11 cases & Visually abnormal and SCC $>500,000$ & 55 & 12 & & FAR 50 & \\
\hline 160 cows, 571 cases & Treatment or cow SCC $>100,000,{ }^{4}$ same day & $84-88^{5}$ & & $67-73$ & FP $15-20$ cows/d & Cavero et al., 2007 \\
\hline 160 cows, 236 cases & Treatment or cow SCC $>400,000,{ }^{4}$ same day & $85-86^{5}$ & & $75-82$ & FP $15-21$ cows $/ \mathrm{d}$ & \\
\hline \multicolumn{7}{|l|}{ Milk color } \\
\hline 4 farms, AMS2, 17 cases & Visually abnormal milk and CMT $\geq 3$, same day & 47 & & & & Hovinen et al., 2006 \\
\hline 1 farm & Visually abnormal milk & 68 & & & FP 78 & Trilk et al., 2008 \\
\hline \multicolumn{7}{|l|}{ Milk SCC } \\
\hline 1 farm, 20 cases & Visually abnormal milk or local signs of the udder ${ }^{3,6}$ & 83 & $13-16$ & & FAR $3-4$ & \multirow{3}{*}{$\begin{array}{l}\text { Kamphuis et al., 2008b } \\
\text { Mollenhorst et al., } 2009\end{array}$} \\
\hline 3 farms, 22 cases & Visually abnormal milk & 55 & 6 & & FAR 174 & \\
\hline 3 farms, 11 cases & Visually abnormal and SCC $>500,000$ & 100 & 6 & & FAR 177 & \\
\hline
\end{tabular}

${ }^{1} \mathrm{AMS} 1$ and AMS2 = different brands of automatic milking systems.

${ }^{2}$ Sensitivity (Se), specificity ( $\mathrm{Sp}$ ), positive predictive value (PPV), false positive alerts (FP), and false alert rate (FAR $=\mathrm{FP}$ alerts $/ 1,000$ cow milkings) were used as measures of performance. The thresholds and mathematical models for alerts and time windows for creating and classifying alerts varied.

${ }^{3}$ Alert periods differed.

$\quad{ }^{4}$ Electrical conductivity measured at cow level.

$\stackrel{5}{5}$ Mathematical models differed.

$\stackrel{2}{\stackrel{2}{\Sigma}}$ SCC measured at cow level. 
not advisable (Biggadike et al., 2002) and would result in increased use of antibiotic treatments.

Reliability of alerts affects the motivation of the farmer to react. Sherlock et al. (2008) pointed out that Sp for classifying healthy quarters is a confusing indicator of detection performance and suggested the use of success rate and false alert rate. This was demonstrated in the study by Hovinen et al. (2006), where Sp for EC was quite high, but the false alert rate was also high (32 false alerts/1,000 cow milkings) in one AMS brand.

The poor results obtained for mastitis detection in AM might be partly explained by the milk fraction analyzed: EC of the milk has been shown to be highest in milk obtained before the milk ejection reflex, the cisternal milk having the best diagnostic value (Woolford et al., 1998; Bruckmaier et al., 2004). In AM, EC is measured after the beginning of milk ejection, and measuring continues throughout the milking. Electrical conductivity is lowest after an MI of 9 to $12 \mathrm{~h}$, and MI should be taken into account in applying EC to mastitis detection in AM (Barth and Worstorff, 2000). Comparison of quarters instead of the absolute EC values is preferable (Nielen et al., 1992; Norberg et al., 2004) because it could eliminate the variation due to breed and parity of the cow, MI, DIM, milk temperature, and composition (Hamann and Zecconi, 1998). Applying time-series models could lead to a better performance of AMS in mastitis detection (de Mol and Ouweltjes, 2001; Biggadike et al., 2002; Hovinen et al., 2006). Meters cannot provide a proper value for EC if clots in the milk disturb the measurement (Norberg et al., 2004) or if the milk yield strongly declines. Proper maintenance of the electrodes is important. de Mol et al. (2001) showed that $25 \%$ of the cows in CM in one farm received indeterminable EC values. Additionally, a cow with clinical mastitis may be too sick to visit the AMU voluntarily.

Milk Color. Milk color changes during clinical mastitis as blood constituents leak from the vessels. A sensor measuring reflected light intensity can be used to measure milk color and detect abnormal milk (Ouweltjes and Hogeveen, 2001; Espada and Vijverberg, 2002). This color sensor analyzes a continuous flow of milk in AM and can detect blood added to the milk at concentrations as low as $0.1 \%$. The conventional visual method using a black strip cup detected only $2.0 \%$ or more blood in the milk (Rasmussen and Bjerring, 2005). It was expected that systems would be able to detect most cases of visually detectable blood in milk under field conditions. In a field study by Hovinen et al. (2006) of a few cases of milk with blood, all were detected but most of the alerts were based on the increase in the yellow color of milk. Whyte et al. (2004) detected all 6 cases with visually red milk with an optical on-line sensor. They demonstrated an Sp of 99.6\%, calculated from nearly 500 samples with $<10^{7}$ red blood cells $/ \mathrm{mL}$. In Hovinen et al. (2006), 11 out of 17 cases of clinical mastitis were detected during a 6 -d period before clinical signs were detected (Table 3). Five of those were detected solely based on milk color and not based on EC, so that milk color added value to the detection system. Green and blue colors were the best indicators for both abnormal milk and clinical mastitis, although they did not correlate well with the appearance of the milk (Kamphuis et al., 2008a). Trilk et al. (2006) tested the same AM system for detecting abnormal milk and had an Se of $68 \%$; however, $78 \%$ of the alarms were FP.

The definition of subclinical mastitis is milk without visual changes (IDF, 1999). Consequently, color index values did not differ between healthy quarters and those with subclinical mastitis (Hovinen et al., 2006; Table 2), in agreement with Ordolff (2002), who reported that absolute color values were not satisfactory for detecting milk with a high SCC, although milk color was related to SCC and lactation stage. However, Wiedemann and Wendl (2003) detected up to $80 \%$ of the samples with high SCC using a spectrophotometric method. Differences in the Se might be explained by different methods of analysis and thresholds for alerts. During a 15-d to 1-mo study period, color alerts were more common than EC alerts at the quarter level (Hovinen et al., 2006). Alerts were occasional, which indicates that some of the alerts were not truly related to abnormal milk or clinical mastitis. Indeed, most of the FP alerts were due to an increased yellow color in the milk, probably reflecting the cow's diet. Milk color can also vary according to the MI (Espada and Vijverberg, 2002).

$\boldsymbol{S C C}$. Milk SCC is the most commonly used indirect indicator of subclinical mastitis (IDF, 1999). According to results from several studies (reviewed by Pyörälä, 2003), the effect of lactation stage, parity, and season have a minor influence on milk SCC of healthy quarters compared with the infection status of the quarter and MI. In AM, on-line SCC measurement is a new method for the detection of subclinical mastitis. Two systems for on-line SCC analysis of milk are currently available:

(1) A direct method: dyeing the nuclei of somatic cells and counting them automatically from a photograph. Milk samples are taken from the cow composite milk.

(2) An indirect method: hydrolysing the DNA of the nuclei of somatic cells and measuring the viscosity of the compound. The system gives estimates 
of SCC similar to a CMT. The milk sample is taken from the first fraction of the milk after milk ejection has started. This method operates at the quarter level.

Mollenhorst et al. (2009) compared indirect on-line quarter milk SCC data with quarter milk SCC determined in a laboratory and with visual detection of abnormal milk (Table 3). Correlation between on-line SCC and laboratory SCC was 0.47. Sensitivity and Sp for detecting visually abnormal foremilk with on-line or laboratory SCC, at a threshold of 500,000 cells/ $\mathrm{mL}$, were nearly similar (Se $55 \%$ and $\mathrm{Sp} 50 \%$, positive predictive value 6 and $4 \%$, respectively), corresponding well with the results of Rasmussen et al. (2005), who used CMT Scandinavian score 4 to 5 as an indicator of abnormal milk (with Se 58\% and Sp 88\%). Differences between laboratory and on-line SCC measurements could be due to the different fractions of the milk studied: milk during the first $30 \mathrm{~s}$ of milking (on-line SCC) was compared with a composite sample of the quarter (laboratory SCC). However, foremilk samples taken after milk ejection should be representative of the quarter composite milk, at least with SCC of 50,000 to 300,000 cells/mL (Wellnitz et al., 2009).

Overall, the correlation on cow composite milk SCC between SCC analyzed in a laboratory or with the indirect on-line SCC method of AMS (as described by Whyte et al., 2004) was 0.76; for quarters with SCC $>200,000$ cells $/ \mathrm{mL}$, the correlation was 0.82 (Kamphuis et al., 2008b). Respective numbers for quarter EC and cow SCC analyzed in a laboratory were 0.48 and 0.33 (Kamphuis et al., 2008b). For quarters having $>200,000$ cells $/ \mathrm{mL}$ analyzed in a laboratory, only $77 \%$ also had an SCC of $>200,000$ cells $/ \mathrm{mL}$ when analyzed with an on-line SCC detector. Mathematical models of mastitis detection in AM using either EC or on-line SCC measurement had as high a Se for detecting 20 quarters with clinical mastitis as a model that combined the 2 parameters (Kamphuis et al., 2008b). However, an online SCC model gave fewer FP alerts than an EC model, and combining the models resulted in a greater decrease in the number of FP alerts. To conclude, on-line SCC measurement is a promising method of mastitis detection, once the technical problems associated with the use of it and proper modeling have been solved.

Multivariate Methods. Nielen et al. (1992) suggested a multivariate approach for mastitis detection, possibly a sequential model based on a meta-analysis of studies on EC for both subclinical and clinical mastitis. After a series of studies they ended up using a neural network technique, which detects patterns irrespective of data distribution, missing data or abnormal values, to distinguish between healthy quarters and those with clinical mastitis (Nielen et al., 1995). They used EC, milk temperature, and yield. Multivariate time-series models using EC, milk temperature, and yield with a Kalman filter (a method to estimate the state of a system on-line) have been developed for detection of subclinical (de Mol et al., 1997, 1999) as well as clinical mastitis (de Mol et al., 1997, 1999, 2001) in CM. A model using EC and milk yield was also created for AM (de Mol and Ouweltjes, 2001). The model became accustomed to a certain level of variables (de Mol et al., 1999), which could be both an advantage and a disadvantage in practice. With a fuzzy logic model for classifying alerts of clinical mastitis as true or false based on EC, and additional information about the cows (de Mol and Woldt, 2001), the number of FP alerts could be reduced. In field tests, a model for detecting illnesses (using cow activity instead of EC) had a higher Se for detecting clinical mastitis than did an actual mastitis detection model (de Mol et al., 2001).

Cavero et al. (2006) developed a model in AM that incorporated EC, milk yield, milk flow rate, and MI. The model used a fuzzy logic support method to aid decision-making that classified results as indicating mastitis, different degrees of likelihood for mastitis, or no mastitis. The results suggested that more informative parameters would be necessary to improve the model. A method using neural networks to imitate brain function with learning abilities was later tested. It used EC, DIM, milk production, and milk flow rate, but the results were inferior compared with the earlier models (Cavero et al., 2008). Using a combination of EC and spectral reflectance measurement in milk, Wiedemann (2004) reported an Se of $73 \%$ for detecting quarters with SCC $>500,000$ cells $/ \mathrm{mL}$ and $85 \%$ for detecting quarters with $>500,000$ cells $/ \mathrm{mL}$ and an IMI.

Variables describing the shape or variability of EC, milk production rate, and milk color for detecting quarters with abnormal milk or clinical mastitis were tested in AM (Kamphuis et al., 2008a). Absolute EC values were important, even though more sophisticated methods use deviation from expected values. Variability and shape of measurement patterns were as important as variables describing the mean or maximum. Variables did not correlate well with milk appearance (Kamphuis et al., 2008a). Subsequently, with promising results, they also used EC, milk production, dead milking time, and milk flow in AM with a decision-tree induction that could handle noisy, imbalanced, and incomplete data such as typical field data (Kamphuis et al., 2010a). The same technique was used including SCC data, still achieving a high Sp but a low Se for clinical mastitis, using a narrow time-frame (Kamphuis et al., 2010b). They also combined on-line SCC and EC measurement in a fuzzy logic model and were able to 
decrease the false alert rate and increase the success rate of clinical mastitis detection 2- to 3-fold compared with EC or SCC measurement alone (Kamphuis et al., 2008b). Normal and abnormal state of the animal could be differentiated with better accuracy than specific diseases when using a fuzzy logic model with milk yield, milk flow, milk EC, and cow activity (Liberati and Zappavigna, 2009). Hassan et al. (2009) reported good results in classifying quarters into noninfected or infected with minor or major bacteria by analyzing, for example, quarter SCC and EC and taking advantage of a neural network technique in CM. Steeneveld et al. (2009) classified mastitis bacteria as gram-negative or gram-positive using cow data that could be made available in AMS, and later ranked the alerts using cow-specific data other than milk measurements in CM (Steeneveld et al., 2010a) and in AM (Steeneveld et al., 2010b). They concluded that many different alerts of AMS should be used but that adding other cowspecific data did not much improve classification of the alerts (Steeneveld et al., 2010b). These highly advanced methods may be developed into commercial solutions in $\mathrm{AM}$ in the future.

\section{RECOMMENDATIONS AND CONCLUSIONS}

Udder health has slightly deteriorated after the introduction of automatic milking, determined by individual cow SCC or an increased proportion of new high-SCC cows. Managing cows under new conditions requires new skills from the farmer, and the situation can be very challenging. Farmers should learn to use new technology in a productive way to manage possible changes in feeding regimens and manage a larger herd in freestalls perhaps after having used tie-stalls. To maintain good udder health, milking frequency should be adapted for every cow according to the state of lactation. For example, postpartum cows should be milked approximately 3 times a day with MI as regular as possible. Four-times-a-day milking should be implemented only at the peak of lactation and only for the cows with the highest milk yield. At the end of lactation, cows should be milked twice a day. Quarter-based milking reduces transfer of bacteria between the quarters of the same cow, but care should be taken to minimize contamination between cows by proper flushing or other techniques for handling the milking equipment between the cows. Special attention should be paid to milking cows with contagious IMI and to efficient detection of new IMI. Intramammary infections can spread from cow to cow via stalls, and preventing milk leakage is important, as is segregating the cows according to their udder health. Effective disinfection of the teats by spraying after milking should be conducted to prevent infections. New cows brought into the herd should be free from IMI.

Adequate overall hygiene and good teat condition are important because dirty teats or teats with hyperkeratosis are not efficiently washed in the automatic cleaning process. Udder hair should be regularly clipped to facilitate cleaning. Barn design and cow comfort (e.g., every cow has a comfortable and clean stall to lie down in) have a great effect on cow and udder cleanliness. Consequently, experts on animal health and welfare should be involved in designing and reconstructing barns with AMS. The AMU settings should be carefully monitored and adjusted to keep the teats in good condition. Milking by the AMU should occur smoothly so that it does not cause distress through a long waiting time or restlessness through unpleasant or painful milking because of incorrect machine settings.

Mastitis detection should be reliable and timely, using the opportunities provided by the AMS, but also by screening cows for example, by SCC every month. The distribution of mastitis-causing bacteria on the farm is known by taking bacterial samples of cows with clinical mastitis and a high SCC, particularly after calving and before drying-off, which is important for planning specific control measures.

The manufacturers of AMS should aim to develop means for automatic evaluation of teat cleanliness and more effective methods for teat cleaning, to further improve detection methods and techniques for clinical and subclinical mastitis, to improve cleaning of all parts of AMU that may spread mastitis bacteria between cows, and to improve teat spraying techniques. Much more effort should be made in educating farmers to exploit the technology provided by the AMS and providing the manuals and software in the native language of the farmer. Researchers must address the open questions concerning the effect of infrequent milking on udder health, species distribution of mastitis-causing bacteria in AM, the effect of systematic failures in teat cup attachment on udder health, and the effect of adjustments of the teat cleaning sequences on teat cleanliness. Researchers should also further improve multivariate detection methods for mastitis, investigate reasons for poor teat condition in some AM farms, and explore routes of transmission of udder pathogens between cows in AMS. With skillful management and careful observation of the cows, good udder health can be maintained in AM. However, "automatic" does not mean that the role of competent staff would in any way be diminished.

\section{REFERENCES}

Abeni, F., M. G. Terzano, M. Speroni, L. Migliorati, M. Capelletti, F. Calza, L. Bianchi, and G. Pirlo. 2008. Evaluation of milk enzymes 
and electrolytes, plasma metabolites, and oxidative status in twin cows milked in an automatic milking system or twice daily in a conventional milking parlor. J. Dairy Sci. 91:3372-3384.

Bach, A., and I. Busto. 2005. Effects on milk yield of milking interval regularity and teat cup attachment failures with robotic milking systems. J. Dairy Res. 72:101-106.

Bade, R. D., D. J. Reinemann, and P. D. Thompson. 2008. Robot versus human pre-milking teat preparation. Pages $184-185$ in NMC Annual Meeting Proc., New Orleans, LA. National Mastitis Council, Madison, WI.

Barth, K., and H. Worstorff. 2000. Influence of different milking intervals on electrical conductivity before alveolar milk ejection in cows. Milchwissenschaft 55:363-365.

Bennedsgaard, T. W., S. Elvstrøm, and M. D. Rasmussen. 2004. Selection of cows for treatment of udder infections in AMS herds. Pages 209-214 in Automatic Milking-A Better Understanding. A. Meijering, H. Hogeveen, and C. J. A. M. de Koning, ed. Wageningen Academic Publishers, Wageningen, the Netherlands.

Berglund, I., G. Pettersson, and K. Svennersten-Sjaunja. 2002. Automatic milking: Effects on somatic cell count and teat-end quality. Livest. Prod. Sci. 78:115-124.

Biggadike, H. J., I. Ohnstad, R. A. Laven, and J. E. Hillerton. 2002. Evaluation of measurements of the conductivity of quarter milk samples for the early diagnosis of mastitis. Vet. Rec. 150:655658.

Bramley, A. J., K. S. Godinho, and R. J. Grindal. 1981. Evidence of penetration of the bovine teat duct by Escherichia coli in the interval between milkings. J. Dairy Res. 48:379-386.

Breen, J. E., M. J. Green, and A. J. Bradley. 2009. Quarter and cow risk factors associated with the occurrence of clinical mastitis in dairy cows in the United Kingdom. J. Dairy Sci. 92:2551-2561.

Bruckmaier, R. M., and M. Hilger. 2001. Milk ejection in dairy cows at different degrees of udder filling. J. Dairy Res. 68:369-376.

Bruckmaier, R. M., J. Macuhova, and H. H. D. Meyer. 2001. Specific aspects of milk ejection in robotic milking: A review. Livest. Prod. Sci. 72:169-176.

Bruckmaier, R. M., D. Weiss, M. Wiedemann, S. Schmitz, and G. Wendl. 2004. Changes of physicochemical indicators during mastitis and the effects of milk ejection on their sensitivity. J. Dairy Res. 71:316-321.

Bull, C., T. Mottram, and H. Wheeler. 1995. Optical teat inspection for automatic milking systems. Comput. Electron. Agric. 12:121-130.

Cavero, D., K.-H. Tölle, C. Buxadé, and J. Krieter. 2006. Mastitis detection in dairy cows by application of fuzzy logic. Livest. Sci. 105:207-213.

Cavero, D., K.-H. Tölle, C. Henze, C. Buxadé, and J. Krieter. 2008. Mastitis detection in dairy cows by application of neural networks. Livest. Sci. 114:280-286.

Cavero, D., K.-H. Tölle, G. Rave, C. Buxadé, and J. Krieter. 2007. Analysing serial data for mastitis detection by means of local regression. Livest. Sci. 110:101-110.

Cook, N. B. 2004. The cow comfort link to milk quality. In Proc. NMC Regional Meeting, Bloomington, MN. National Mastitis Council, Madison, WI.

de Koning, C. J. A. M. 2010. Automatic milking-A common practice on dairy farms. Pages 52-67 in Proc. First North American Conference on Precision Dairy Management, Toronto, Canada. Omnipress, Madison, WI

de Mol, R. M., A. Keen, G. H. Kroeze, and J. M. F. H. Achten. 1999. Description of a detection model for oestrus and diseases in dairy cattle based on time series analysis combined with a Kalman filter. Comput. Electron. Agric. 22:171-185.

de Mol, R. M., G. H. Kroeze, J. M. F. H. Achten, K. Maatje, and W. Rossing. 1997. Results of a multivariate approach to automated oestrus and mastitis detection. Livest. Prod. Sci. 48:219-227.

de Mol, R. M., and W. Ouweltjes. 2001. Detection model for mastitis in cows milked in an automatic milking system. Prev. Vet. Med. $49: 71-82$. de Mol, R. M., W. Ouweltjes, G. H. Kroeze, and M. M. W. B. Hendriks. 2001. Detection of estrus and mastitis: Field performance of a model. Appl. Eng. Agric. 17:399-407.

de Mol, R. M., and W. E. Woldt. 2001. Application of fuzzy logic in automated cow status monitoring. J. Dairy Sci. 84:400-410.

de Vliegher, S., H. Laevens, G. Opsomer, K. Fischer, I. Christiaens, I. Laquiere, T. Hemling, M. McKinzie, and A. de Kruif. 2003. Effect of transition from conventional milking to robotic milking on teat skin and teat end condition. Acta Vet. Scand. Suppl. $98: 318-319$.

Dohmen, W., F. Neijenhuis, and H. Hogeveen. 2010. Relationship between udder health and hygiene on farms with an automatic milking system. J. Dairy Sci. 93:4019-4033.

Dzidic, A., J. Macuhova, and R. M. Bruckmaier. 2004b. Effects of cleaning duration and water temperature on oxytocin release and milk removal in an automatic milking system. J. Dairy Sci. $87: 4163-4169$.

Dzidic, A., D. Weiss, and R. M. Bruckmaier. 2004a. Oxytocin release, milk ejection and milking characteristics in a single stall automatic milking system. Livest. Prod. Sci. 86:61-68.

Espada, E., and H. Vijverberg. 2002. Milk colour analysis as a tool for the detection of abnormal milk. Pages IV 28-IV 38 in the Proc. of the First North American Conference on Robotic Milking, March 20-22, Canada, Wageningen Pers, Wageningen, the Netherlands.

European Council. 2004. Regulation (EC) No 853/2004 of the European Parliament and of the Council laying down specific hygiene rules for on the hygiene of foodstuffs. http://eur-lex.europa. eu/LexUriServ/LexUriServ.do?uri=OJ:L:2004:139:0055:0205:EN: PDF

Forsbäck, L., H. Lindmark-Månsson, A. Andrén, M. Åkerstedt, and K. Svennersten-Sjaunja. 2009. Udder quarter milk composition at different levels of somatic cell count in cow composite milk. Animal 3:710-717.

Gygax, L., I. Neuffer, C. Kaufmann, R. Hauser, and B. Wechsler. 2007. Comparison of functional aspects in two automatic milking systems and auto-tandem milking parlors. J. Dairy Sci. 90:4265-4274.

Halasa, T., M. Nielen, A. P. W. de Roos, R. van Hoorne, G. de Jong, T. J. G. M. Lam, T. van Werven, and H. Hogeveen. 2009. Production loss due to new subclinical mastitis in Dutch dairy cows estimated with a test-day model. J. Dairy Sci. 92:599-606.

Hamann, J., and A. Zecconi. 1998. Evaluation of the electrical conductivity of milk as a mastitis indicator. Pages 5-26 in Bull. 334. Int. Dairy Fed., Brussels, Belgium.

Hassan, K. J., S. Samarashinge, and M. G. Lopez-Benavides. 2009. Use of neural networks to detect minor and major pathogens that cause bovine mastitis. J. Dairy Sci. 92:1493-1499.

Hill, A. E., A. L. Green, B. A. Wagner, and D. A. Dargatz. 2009. Relationship between herd size and annual prevalence of and primary antimicrobial treatments for common diseases on dairy operations in the United States. Prev. Vet. Med. 88:264-277.

Hillerton, J. E. 1991. The effects of milking frequency on mastitis. Pages 61-69 in Proc. British Mast. Conf., Stoneleigh, UK. CibaGeigy Agrochemicals, Cambridge, UK.

Hillerton, J. E., J. W. Pankey, and P. Pankey. 2002. Effect of overmilking on teat condition. J. Dairy Res. 69:81-84.

Hogeveen, H., E. N. Noordhuizen-Stassen, J. F. Schreinemakers, and A. Brand. 1991. Development of an integrated knowledge-based system for management support on dairy farms. J. Dairy Sci. 74:4377-4384.

Hogeveen, H., W. Ouweltjes, C. J. A. M. de Koning, and K. Stelwagen. 2001. Milking interval, milk production and milk flow-rate in an automatic milking system. Livest. Prod. Sci. 72:157-167.

Hopster, H., R. M. Bruckmaier, J. T. N. van der Werf, S. M. Korte, J. Macuhova, G. Korte-Bouws, and C. G. van Reenen. 2002. Stress responses during milking; Comparing conventional and automatic milking in primiparous dairy cows. J. Dairy Sci. 85:3206-3216.

Hovinen, M., A.-M. Aisla, and S. Pyörälä. 2005. Visual detection of technical success and effectiveness of teat cleaning in two automatic milking systems. J. Dairy Sci. 88:3354-3362. 
Hovinen, M., A.-M. Aisla, and S. Pyörälä. 2006. Accuracy and reliability of mastitis detection with electrical conductivity and milk colour measurement in automatic milking. Acta Agric. Scand. A $56: 121-127$.

Hovinen, M., M. Haveri, P. Hyvönen, and S. Pyörälä. 2010. Sources of liner contamination and effect of back-flushing of teat cups on isolation of Staphylococcus aureus. Pages 714-715 in Mastitis research into practice. Proc 5th IDF Mastitis Conference, Christchurch, New Zealand. J. E. Hillerton, ed.VetLearn, Wellington, New Zealand.

Hovinen, M., and S. Pyörälä. 2002. Observations on udder health of automatically milked cows in Finland. Page IV 71-IV 74 in the Proc. First North American Conference on Robotic Milking, Canada. Wageningen Pers, Wageningen, the Netherlands.

Hovinen, M., M. D. Rasmussen, and S. Pyörälä. 2009. Udder health of cows changing from tie stall or free stall with conventional milking to free stall with either conventional or automatic milking. J. Dairy Sci. 92:3696-3703.

International Dairy Federation. 1999. Suggested interpretation of mastitis terminology. Pages 3-26 in IDF Bulletin 338. IDF, Brussels, Belgium.

Ipema, A. H., and E. Benders. 1992. Production, duration of machinemilking and teat quality of dairy cows milked 2, 3 or 4 times daily with variable intervals. Pages $244-252$ in Proc. Int. Symp. Prospects for Automatic Milking. A. H. Ipema, A. C. Lippus, J. H. M. Metz, and W. Rossing, ed. Pudoc Scientific Publishers, Wageningen, the Netherlands.

ISO. 2007. ISO/DIS 20966: Automatic milking installations-Requirements and testing. International Organisation for Standardisation, Geneva, Switzerland.

Jago, J. G., K. L. Davis, P. J. Copeman, and M. M. Woolford. 2006. The effect of pre-milking teat-brushing on milk processing time in automated milking system. J. Dairy Res. 73:187-192.

Kaihilahti, J., A. Suokannas, and S. Raussi. 2007. Observation of cow behaviour in an automatic milking system using web-based video recording technology. Biosystems Eng. 96:91-97.

Kamphuis, C., H. Mollenhorst, A. Feelders, D. Pietersma, and H. Hogeveen. 2010a. Decision-tree induction to detect clinical mastitis with an automatic milking system. Comput. Electron. Agric. 70:60-68.

Kamphuis, C., H. Mollenhorst, J. A. P. Heesterbeek, and H. Hogeveen. 2010b. Data mining to detect clinical mastitis with automatic milking. Pages 569-572 in Mastitis Research into Practice. Proc. 5th IDF Mast. Conf., Christchurch, New Zealand. J. E. Hillerton, ed. VetLearn, Wellington, New Zealand.

Kamphuis, C., D. Pietersma, R. Tol, M. van der Wiedemann, and H. Hogeveen. 2008a. Using sensor data patterns from an automatic milking system to develop predictive variables for classifying clinical mastitis and abnormal milk. Comput. Electron. Agric. 62:169-181.

Kamphuis, C., R. Sherlock, J. Jago, G. Mein, and H. Hogeveen. 2008b. Automatic detection of clinical mastitis is improved by in-line monitoring of somatic cell count. J. Dairy Sci. 91:4560-4570.

Klaas, I. C., M. Bjerring, and C. Enevoldsen. 2008. Risk factors for teat end callosity in dairy farms operating with automatic milking system (AMS). Page 174 in Automatic Milking-A Better Understanding. A. Meijering, H. Hogeveen, and C. J. A. M. de Koning, ed. Wageningen Academic Publishers, Wageningen, the Netherlands.

Klei, L. R., J. M. Lynch, D. M. Barbano, P. A. Oltenacu, A. J. Lednor, and D. K. Bandler. 1997. Influence of milking three times a day on milk quality. J. Dairy Sci. 80:427-436.

Knappstein, K., and J. Reichmuth. 2000. Detection of clinical mastitis during automatic milking using data on milk electrical conductivity and yield. Pages 116-117 in in Robotic Milking. Proc Int. Symp. Lelystad 2000. H. Hogeveen, and A. Meijering, ed. Wageningen Pers, Wageningen, the Netherlands.

Knappstein, K., N. Roth, H.-G. Walte, J. Reichmuth, B. A. Slaghuis, R. T. Ferwerda-van Zonneveld, and A. Mooiweer. 2004. Effectiveness of automatic cleaning of udder and teats and effects of hygiene management: Report on effectiveness of cleaning procedures applied in different automatic milking systems. Deliverable D14. Accessed Nov. 30, 2004. www.automaticmilking.nl/project results/ reports.

Köhn, F., S. König, and M. Gauly. 2007. Influence of milk production traits and genetic effects on milking frequency in automatic milking system. Zuchtungskunde 79:287-297.

Kruip, T. A. M., H. Morice, M. Robert, and W. Ouweltjes. 2002. Robotic milking and its effect on fertility and cell counts. J. Dairy Sci. 85:2576-2581.

Liberati, P., and P. Zappavigna. 2009. Improving the automated monitoring of dairy cows by integrating various data acquisition systems. Comput. Electron. Agric. 68:62-67.

Lopez-Benavides, M. G., J. H. Williamson, J. E. McGowan, S. J. LacyHulbert, J. G. Jago, K. L. Davis, and M. W. Woolford. 2006. Mastitis in cows milked in automated or conventional milking system in New Zealand. Pages 252-257 in Proc. New Zealand Soc. Anim. Prod. Napier, New Zealand.

Maatje, K., P. J. M. Huijsmans, W. Rossing, and P. H. Hogewerf. 1992. The efficacy of in-line measurement of quarter milk electrical conductivity, milk vield and milk temperature for the detection of clinical and subclinical mastitis. Livest. Prod. Sci. 30:239-249.

Mačuhová, J., V. Tančin, and R. M. Bruckmaier. 2003. Oxytocin release, milk ejection and milk removal in a multi-box automatic milking system. Livest. Prod. Sci. 87:237-244.

Mačuhová, J., V. Tančin, and R. M. Bruckmaier. 2004. Oxytocin release and milk removal after delayed or long-lasting teat cup attachment during automatic milking. Livest. Prod. Sci. 87:237-244.

Mein, G. A., and M. D. Rasmussen. 2008. Performance evaluation of systems for automated monitoring of udder health: Would the real gold standard please stand up? Pages 259-266 in Mastitis control-From Science to Practice. Proc. Int. Conf. Hague, the Netherlands. T. J. G. M. Lam, ed. Wageningen Academic Publishers, Wageningen, the Netherlands.

Melin, M., H. Wiktorsson, and A. Christiansson. 2002. Teat cleaning efficiency before milking in Delaval $\mathrm{VMS}^{\mathrm{TM}}$ versus conventional manual cleaning, using Clostridium tyrobutyricum spores as marker. Pages II60-II63 in the Proc. First North American Conference on Robotic Milking, Canada. Wageningen Pers, Wageningen, the Netherlands.

Miller, R. H., L. A. Fulton, B. Erez, W. F. Williams, and R. E. Pearson. 1995. Variation in distances among teats of Holstein cows: Implications for automated milking. J. Dairy Sci. 78:1456-1462.

Milner, P., K. L. Page, and J. E. Hillerton. 1997. The effects of early antibiotic treatment following diagnosis of mastitis detected by a change in the electrical conductivity of milk. J. Dairy Sci. 80:859863.

Mollenhorst, H., P. P. J. van der Tol, and H. Hogeween. 2009. Mastitis detection: Visual observation compared to inline quarter and milking somatic cell count. Pages 307-314 in Precision Livestock Farming. C. Lokhorst, and P. W. G. Groot Koerkamp, ed. Wageningen Academic Publishers, the Netherlands.

Mottram, T. 1997. Requirements for teat inspection and cleaning in automatic milking systems. Comput. Electron. Agric. 17:63-77.

Mulder, H. A., A. F. Groen, G. De Jong, and P. Bijma. 2004. Genotype $\times$ environment interaction for yield and somatic cell score with automatic and conventional milking systems. J. Dairy Sci $87: 1487-1495$.

Neijenhuis, F., H. W. Barkema, H. Hogeveen, and J. P. T. M. Noordhuizen. 2000. Classification and longitudinal examination of callused teat ends in dairy cows. J. Dairy Sci. 83:2795-2804.

Neijenhuis, F., H. W. Barkema, H. Hogeveen, and J. P. T. M. Noordhuizen. 2001b. Relationship between teat-end callosity and occurrence of clinical mastitis. J. Dairy Sci. 84:2664-2672.

Neijenhuis, F., K. Bos, O. C. Sampimon, J. Poelarends, J. E. Hillerton, C. Fossing, and J. Dearing. 2004. Changes in teat condition in Dutch herds converting from conventional to automated milking. Pages 141-147 in Automatic Milking-A Better Understanding. A. Meijering, H. Hogeveen, and C. J. A. M. de Koning, ed. Wageningen Academic Publishers, Wageningen, the Netherlands.

Neijenhuis, F., J. W. G. Heinen, and H. Hogeveen. 2010. Risk factors for udder health when milking with an automatic milking sys- 
tem. Pages 230-234 in Mastitis Research into Practice. Proc. 5th IDF Mast. Conf., Christchurch, New Zealand. J. E. Hillerton, ed. VetLearn, Wellington, New Zealand.

Neijenhuis, F., G. H. Klungel, and H. Hogeveen. 2001a. Recovery of cow teats after milking as determined by ultrasonographic scanning. J. Dairy Sci. 84:2599-2606.

Nielen, M., H. Deluyker, Y. H. Schukken, and A. Brand. 1992. Electrical conductivity of milk: Measurement, modifiers, and meta analysis of mastitis detection performance. J. Dairy Sci. 75:606-614.

Nielen, M., M. H. Spigt, Y. H. Schukken, H. A. Deluyker, K. Maatje, and A. Brand. 1995. Application of a neural network to analyse on-line milking parlour data for the detection of clinical mastitis in dairy cows. Prev. Vet. Med. 22:15-28.

Norberg, E., H. Hogeveen, I. R. Korsgaard, N. C. Friggens, K. H. M. N. Sloth, and P. Løvendahl. 2004. Electrical conductivity of milk: Ability to predict mastitis status. J. Dairy Sci. 87:1099-1107.

Olde Riekerink, R. G. M., H. W. Barkema, W. Veenstra, F. E. Berg, H. Stryhn, and R. N. Zadoks. 2007. Somatic cell count during and between milkings. J. Dairy Sci. 90:3733-3741.

Ordolff, D. 2002. Lactation dependent variation in colour of the foremilk. Milchpraxis 40:174-175.

Ouweltjes, W., and H. Hogeveen. 2001. Detecting abnormal milk through colour measuring. Pages 217-219 in NMC Annual Meeting Proc., Reno, Nevada. National Mastitis Council, Madison, WI.

Pankey, J. W., R. J. Eberhart, A. L. Cuming, R. D. Daggett, R. J. Farnsworth, and C. K. McDuff. 1984. Uptake on postmilking teat antisepsis. J. Dairy Sci. 67:1336-1353.

Pedersen, L. H., and T. W. Bennedsgaard. 2006. Udder health in dairy herds converting to automatic milking systems - Bacteriology and cell count pattern. Pages 26-31 in Proc. Cattle Consulting Days 2006. Nyborg, Frederiksberg Bogtrykkeri, Denmark.

Persson Waller, K., and H. Unnerstad. 2004. Klebsiellamastit-Ett potentiellt gissel för mjölkproducenten. Svensk Veterinärtidning. 10:11-17. (Klebsiella mastitis-A potential scourge for milk producer).

Persson Waller, K., T. Westermark, T. Ekman, and K. SvennerstenSjaunja. 2003. Milk leakage-An increased risk in automatic milking. J. Dairy Sci. 86:3488-3497.

Petermann, M., C. Rittershaus, B. Kloppert, H. Seufert, and M. Zschöck. 2002. Automatic milking systems: Udder health and milk flow profiles. Pages IV 75-IV 77 in Proc. First North American Conference on Robotic Milking, Canada. Wageningen Pers, Wageningen, the Netherlands.

Poelarends, J. J., O. C. Sampimon, F. Neijenhuis, J. D. H. M. Miltenburg, J. E. Hillerton, J. Dearing, and C. Fossing. 2004. Cow factors related to the increase of somatic cell count after introduction of automatic milking. Pages 148-154 in Automatic Milking-A Better Understanding. A. Meijering, H. Hogeveen, and C. J. A. M. de Koning, ed. Wageningen Academic Publishers, Wageningen, the Netherlands.

Pyörälä, S. 2003. Indicators of inflammation in the diagnosis of mastitis. Vet. Res. 34:565-578.

Rasmussen, M. D. 1993. Influence of switch level of automatic cluster removers on milking performance and udder health. J. Dairy Res. 60:287-297.

Rasmussen, M. D. 2004. Detection and separation of abnormal milk in automatic milking systems. Pages 189-197 in Automatic Milking-A Better Understanding. A. Meijering, H. Hogeveen, and C. J. A. M. de Koning, ed. Wageningen Academic Publishers, Wageningen, the Netherlands.

Rasmussen, M. D. 2005. Visual scoring of clots in foremilk. J. Dairy Res. 72:406-414.

Rasmussen, M. D. 2006b. Automatic milking and udder health: An overview. Pages 368-375 in Comp. 24th World Buiatrics Congress, Nice, France. H. Navetat, and F. Schelcher, ed. World Association for Buiatrics, Paris, France.

Rasmussen, M. D. 2006a. Sensitivitet og specificitet for frasortering af normal mælk I AMS. [Sensitivity and specificity for diversion of abnormal milk in AMS]. Landbrugsinfo-Byggeri og Teknik nr. 1475. Updated April 16, 2010; accessed August 20, 2010.
Rasmussen, M. D., T. W. Bennedsgaard, and L. H. Pedersen. 2007. Changes in quarter yield and milking frequency during clinical mastitis. Pages 214-215 in NMC Annual Meeting Proc., San Antonio, TX. National Mastitis Council, Madison, WI.

Rasmussen, M. D., and M. Bjerring. 2005. Visual scoring of milk mixed with blood. J. Dairy Res. 72:257-263.

Rasmussen, M. D., M. Bjerring, and F. Skjøth. 2005. Visual appearance and CMT score of foremilk of individual quarters in relation to cell count of cows milked automatically. J. Dairy Res. $72: 49-56$

Rasmussen, M. D., J. Y. Blom, L. A. H. Nielsen, and P. Justesen. 2001. Udder health of cows milked automatically. Livest. Prod. Sci. $72: 147-156$.

Rasmussen, M. D., and T. C. Hemling. 2002. The influence of automatic teat spraying on teat condition. Pages $166-167$ in NMC Annual Meeting Proc., Orlando, FL. National Mastitis Council, Madison, WI.

Schreiner, D. A., and P. L. Ruegg. 2003. Relationship between udder and leg hygiene scores and subclinical mastitis. J. Dairy Sci. $86: 3460-3465$

Schuiling, E. 1992. Teat cleaning and stimulation. Pages 164-168 in Prospects for Automatic Milking. Proc. Int. Symp. Prospects Automatic Milking, Wageningen, the Netherlands. Wageningen Publishers, Wageningen, the Netherlands.

Schuiling, H. J., and F. Neijenhuis. 2004. Effectiveness of optimized teat cup cleaning in the prevention of mastitis pathogens transfer. Deliverable 18 on EU-Project "Implications of the introduction of automatic milking on dairy farms." Accessed June 22, 2010. www. automaticmilking.nl.

Schukken, Y. H., D. J. Wilson, F. Welcome, L. Garrison-Tikofsky, and R. N. Gonzalez. 2003. Monitoring udder health and milk quality using somatic cell counts. Vet. Res. 34:579-596.

Sherlock, R., H. Hogeveen, G. Mein, and M. D. Rasmussen. 2008. Performance evaluation of systems for automated monitoring of udder health: Analytical issues and guidelines. Pages 275-282 in Mastitis Control - From Science to Practice. T. J. G. M. Lam, ed. Proc. Int. Conf., Haag, the Netherlands. Wageningen Academic Publishers, Wageningen, the Netherlands.

Smith, T. W., R. J. Eberhart, S. B. Spencer, E. M. Kesler, G. L. Hargrove, R. W. Wilson, and C. W. Heald. 1985. Effect of automatic backflushing on number of new intramammary infections, bacteria on teatcup liners, and milk iodine. J. Dairy Sci. 68:424-432.

Steeneveld, W., H. Hogeveen, H. W. Barkema, J. van den Broek, and R. B. M. Huirne. 2008. The influence of cow factors on the incidence of clinical mastitis in dairy cows. J. Dairy Sci. 91:13911402 .

Steeneveld, W., L. C. van der Gaag, H. W. Barkema, and H. Hogeveen. 2009. Providing probability distributions for the causal pathogen of clinical mastitis using naive Bayesian networks. J. Dairy Sci. 92:2598-2609.

Steeneveld, W., L. C. van der Gaag, H. W. Barkema, and H. Hogeveen. 2010a. Simplify the interpretation of alert lists for clinical mastitis in automatic milking systems. Comput. Electron. Agric. 71:50-56.

Steeneveld, W., L. C. van der Gaag, W. Ouweltjes, H. Mollenhorst, and H. Hogeveen. 2010b. Discriminating between true-positive and false-positive clinical mastitis alerts from automatic milking system. J. Dairy Sci. 93:2559-2568.

Stefanowska, J., M. Plavsic, A. H. Ipema, and M. M. W. B. Hendriks. 2000. The effect of omitted milking on the behavior of cows in the context of cluster attachment failure during automatic milking. Appl. Anim. Behav. Sci. 67:277-291.

Stelwagen, K., and S. J. Lacy-Hulbert. 1996. Effect of milking frequency on milk somatic cell count characteristics and mammary secretory cell damage in cows. Am. J. Vet. Res. 57:902-905.

Thiel, C. C., C. L. Thomas, D. R. Westgarth, and B. Reiter. 1969. Impact force as a possible cause of mechanical transfer of bacteria to the inferior of the cow's teat. J. Dairy Res. 36:179-197.

Trilk, J., K. Münch, and C. Franke. 2006. Untersuchungen zur feststellung von eutergesundheitsstörungen und Rohmilchveränderungen mit dem MQC und weiteren technischen einrichtungen beim au- 
tomatischen melksystem Lely Astronaut. Pages 80-89 in Schriftenreihe des Landesamtes für Verbraucherschutz, Landwirtschaft und Flurneuordnung, Reihe Landwirtschaft, Band 7 Heft V. MLUV, Branderburg, Germany.

Tuiskunen, S., M. Hovinen, and S. Pyörälä. 2006. Klebsiella utaretulehduksen aiheuttajana-Kirjallisuuskatsaus ja tapausselostus. Suomen Eläinlääkärilehti 112:491-495. (Klebsiella as mastitis causing agent-Literature review and a case report).

Weiss, C., M. Hilger, H. H. D. Meyer, and R. M. Bruckmaier. 2002. Variable milking intervals and milk composition. Milchwissenschaft 57:246-249.

Wellnitz, O., M. G. Doherr, M. Woloszyn, and R. M. Bruckmaier. 2009. Prediction of total quarter milk somatic cell counts based on foremilk sampling. J. Dairy Res. 76:326-330.

Wendt, K., and S. Pallas. 2004. Mastitisprädispositionen im automatischen Melksystem (AMS). Tierärztl. Prax. 32(G):257-262.

Whyte, D. S., R. G. Orchard, P. Cross, A. Wilson, R. W. Claycomb, and G. A. Mein. 2004. Seeing red: Automated detection of blood in milk. Pages 241-242 in Automatic Milking-A Better Understanding. A. Meijering, H. Hogeveen, and C. J. A. M. de Koning, ed. Wageningen Academic Publishers, Wageningen, the Netherlands.
Wiedemann, M. 2004. Überwachung der Eutergesundheit bei Milchkühen durch Kombination verscieneder chemisch-physikalischer Messwerte. PhD Diss. Tech. Univ., München, Germany.

Wiedemann, M., and G. Wendl. 2003. The use of colour measurement for the in-line determination of milk quality during milking. Landtechnik. 58:272-273.

Wirtz, N., E. Tholen, H. Spiekers, W. Zahres, E. Pfeffer, and W. Trappmann. 2004. Comparison between automatic and conventional milking concerning milk performance and feed amount. Zuchtungskunde 76:321-334.

Woolford, M. W., J. H. Williamson, and H. W. Henderson. 1998. Changes in electrical conductivity and somatic cell count between milk fractions from subclinically infected with particular mastitis pathogens. J. Dairy Res. 65:187-198.

Zecconi, A., R. Piccinini, G. Casirani, E. Binda, and L. Migliorati. 2004. Introduction of AMS in Italian dairy herds: Effects on teat tissues, intramammary infection risk, and spread of contagious pathogens. Pages 161-167 in Automatic Milking-A Better Understanding. A. Meijering, H. Hogeveen, and C. J. A. M. de Koning, ed. Wageningen Academic Publishers, Wageningen, the Netherlands. 